https://doi.org/10.5817/NR2018-2-14

\section{Jeden z posledních českých encyklopedistů zemřel}

Ve věku 87 let opustil akademický svět doc. PhDr. Václav Huňáček, CSc. Jeho ztráta je nenahraditelná. Ǩíci, že působil více jak půl století na Filozofické fakultě Univerzity Karlovy, nejdéle na katedře rusistiky a naposledy na Ústavu východoevropských studií, by bylo klišé. Jeho odborný, vědecký, pedagogický a publikační záběr byl nekonečný. Mezi obory, v nichž vynikal, patřila především rusistika, dějiny a současnost východního křestanství a kultury a ojedinělé znalosti zeměvědných vztahů mezi Českem a zbytkem světa, zejména vztahy zemí českých a Ruska nebo Ameriky.

Výčet vědního zaměření, specializací a činnosti v odborných grémiích či publikační činnosti by vydal na samostatnou encyklopedii. Jeho univerzální znalosti byly vždy předmětem širokého obdivu a uznání, od ocenění National Geographic Society po řadu domácích cen, napřr. Medaile Josefa Jungmanna nebo Medaile J.A. Komenského. Do hloubky ovládal četné obory historické, přirodovědné, etnografii, folkloristiku, geografii a další. KRíci o něm, že byl hlavně slavista a jazykovědec, by bylo málo. Směle mohl poskytnout fundované přednášky z byzantologie, literatury, mezinárodních vztahů, či otázek teologických nebo politologických. Jeho kulturní přehled byl bezbřehý i v mezinárodním kontextu.
Nikdo neví, v kolika jazycích se vlastně domluvil. Ŕíkalo se, že až dvaceti dvěma.

Samozřejmě, že vzhledem ke kmenovému zařazení na FF UK vynikal zejména v oborech slavistických. $\mathrm{V}$ rámci slavistiky mu byla vlastní slavistika všeobecná, srovnávací i dějiny slavistiky. Známé byly třeba jeho statě a přednášky o Polabských Slovanech, byl odborníkem ve staroslověnštině a církevní slovanštině, $\mathrm{v}$ translatologii a onomastice i v aplikované lingvistice. Věnoval se vývoji ruského jazyka. Ojedinělé bylo jeho postavení prri studiu dějin východních kultur a hlavně křestanství, zeměvědy a reálií Ruska včetně dějin kulturních institucí (hlavně církevních). Až do posledních let byly nabity posluchači jeho přednášky, které se věnovaly dějinám a kulturním vztahům česko-ruským, mezislovanským a slovansko-neslovanským. V oboru geopolitických a kulturních reálií byl nepřekonatelným znalcem.

Fenoménem Huňáčkovy renesanční osobnosti bylo „průvodcování“. Byl to on, kdo stál u kolébky základní metodiky a praxe průvodcovské činnosti. Právě $\mathrm{v}$ tomto oboru mohl dát průchod nejen všestranným znalostem, ale předvést v praxi, jak dokáže být věda zajímavá, struhující a zábavná, když někdo lidem dokáže předvést svět přímo $\mathrm{v}$ terénu v názorných souvislostech. Měl rád studenty a rád s nimi trávil i většinu svého volného času. Stovky studentů a přátel nikdy nezapomenou na jeho obohacující výpravy za poznáním zemí českých i daleké ciziny. „Provádění“ ovládal geniálně nejen prakticky, ale věnoval se i teorii 
cizojazyčného průvodcování, české vlastivědě pro cizince zejména $\mathrm{v}$ kontextu evropské kultury a náboženství. Dodnes nepřekonanou „biblí“ všech průvodců se stala Huňáčkova Metodika tematické činnosti průvodce, která poprvé vyšla $\mathrm{v}$ roce 1983 a doznala mnoha reedic.

Z rusistických oborů se věnoval zejména zeměvědě, vývoji jazyka a kulturní historii včetně náboženství a česko-ruským vztahům. Z jeho jazykových prací zaslouží pozornost jeho podíl na sborníku Texty ke studiu vývoje ruského jazyka, který poprvé vyšel roku 1959 a poté $\mathrm{v}$ mnoha reedicích (naposledy roku 1981). $\mathrm{Z}$ dalších prací byly přínosné statě a studie První rusisté v časopisu Ruský jazyk č. 3, ročník 1967/1968, nebo K počátkưm české rusistiky, př́spěvek věnovaný sborníku Práce z dějin slavistiky č. X (1985). Nelze pominout ani jeho lví podíl na

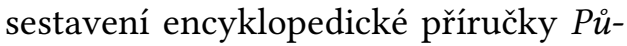
vod zemépisných jmen (1976). Zajímavá je stat' Sarkandr-Masaryk (etymologické souvislosti jmen prvního moravskoslezského světce a prvního prezidenta ČSR), která vyšla v časopisu Souvislosti č. $2 \mathrm{v}$ roce 1995.

Z díla, které Huňáček věnoval česko-ruským vztahům, není jediného studenta rusistiky na FF UK, který by neznal doslova zpaměti Huňáčkovy kapitoly ve skriptech SSSR - země a kultura (СССР - страна и культура), první vydání z roku 1982, poslední 1989. Podobným originálním nepostradatelným kompendiem bylo Srovnávací minimum SSSR-ČSSR pro prưvodce z roku 1977. $\mathrm{Z}$ dílčích prací zaslouží jistě pozornost studie Slovanská Sázava a česko-uhersko-ruské vztahy v XI. století, publikovaná v Bulletinu ÚRJL v roce 1970. Z novějších pak kupř́kladu $K$ dědictví Komenského $v$ Rusku ze sborníku Pocta Univerzity Karlovy J. A. Komenskému (1992).

Na sklonku vědecké kariéry se Huňáček věnoval zejména ruské a obecně východoslovanské křestanské tradici, kde je nezbytné prripomenou jeho stat’ Východoslovanské křestanství a starši tradice uveřejněnou ve sborníku Studie $\mathrm{k}$ dějinám a kultuře východních Slovanů č. XX z roku 1992, nebo prríspěvek $V y ́$ chodokřestanská ortodoxie a heterodoxie ve Zpravodaji české koordinační rady SPNV č. 9/10 z roku 2000.

Ze samostatných monografií je dnes antikvariátní vzácností zejména jeho kniha Republika naša z roku 1969.

Právě pro obrovské faktografické znalosti, hluboký vhled do širokého prizmatu historických a kulturních kontextů měl však doc. Huňáček i jeden problém. Rád zkoumal věci do hloubky v rozvětvených souvislostech, a tak jsme ho na katedře jen s obtížemi uměli přesvědčit k sepsání jeho obrovských znalostí do nějakých kompaktních monografií. Byl přesvědčený, že toho stále ještě neví dost, ačkoliv toho ve skutečnosti věděl možná víc, než většina jeho kolegů na katedře dohromady. Nestál o pocty. Ani to ty vědecké. A tak jeho odkaz je povětšinou roztroušen ve stovkách článků, studií, skript, učebních a metodických textů, proslovených přednášek, př́ležitostných tisků, nebo jako spoluautorské statě v kolektivních kompendiích. 
Huňáčkův vklad do jednotlivých vědních oborů bude nepochybně předmětem dalšího zkoumání a hodnocení. Avšak společným a nadřazeným jmenovatelem je, že nás opustil člověk, který měl encyklopedické vědomosti, všestranné poznatky z mnoha vědních oborů, skutečný polyhistor. Znal jsem Václava Huňáčka více jak čtyřicet let. Nejprve jako jeho student, potom jsem s ním více jak desetiletí sdílel pracovnu i stůl na FF UK a zůstal mým př́telem a nenahraditelným kolegou až dosud. Mimo jiné i pro svůj optimismus, neopakovatelný smysl pro humor a recesi, které si udržel do posledních dnů.

Znám stovky jeho bývalých studentů a kolegů, a tak vím, že to hlavní, co Huňáček dokázal následovníkủm předat, bylo poselství, že chceš-li něčemu rozumět, musíš o tom nejprve něco vědět. Pro několik generací vysokoškolských absolventů byl představitelem zdravého kritického rozumu, touhy stále se učit a vášnivě poznávat věci a děje $v$ kontextech, umění nejprve věci vidět a pak je teprve hodnotit.

Huňáčkův odchod je pro dnešní dobu symbolický. Odešel jeden z představitelů vědecké a pedagogické, ale hlavně lidské generace, která nepodlehla dnešní mainstreamové představě velké části populace, která si myslí, že všemu rozumí, a přitom máloco ví. Václav Huňáček byl pravým generačním a myšlenkovým opakem. Proto je jeho odchod pro mnohé tak tíživý.

Michail Odarčenko
https://doi.org/10.5817/NR2018-2-15

\section{Květuše Lepilová jubilující}

V dubnu letošního roku oslavila své polokulaté životní výročí významná česká rusistka doc. PhDr. Květuše Lepilová, CSc. Jubilantka se narodila 9. dubna 1933 v Ostravě - Mariánských Horách, ale až do konce války žila rodina $\mathrm{v}$ Jistebníku. Tam otec jubilantky jako učitel a zanícený hudebník vedl dětský sbor Jistebnických zpěváčků a jubilantka v něm pod vedením svého otce už ve svých čtyřech letech zpívala sólo. Po válce se rodina přestěhovala do Brna a otec jubilantky, pozdější profesor Pedagogické fakulty tehdejší Univerzity J. Ev. Purkyně PhDr. František Lýsek, DrSc., založil Brněnský dětský sbor; vedl jej téměř až do své smrti v roce 1977. Jako členka tohoto sboru měla možnost poznat řadu významných osobností hudební kultury.

$\mathrm{V}$ Brně absolvovala jubilantka $\mathrm{v}$ roce 1951 reálné gymnázium. I když nešla přímo ve stopách svého otce, možno říct, že jablko od pověstného stromu nepadlo daleko: kromě gymnázia ukončila $\mathrm{v}$ roce 1953 studium konzervatoře státní zkouškou ze hry na klavír a sólového zpěvu. $\mathrm{V}$ roce 1951 se zapsala na brněnskou filozofickou fakultu, kde v roce 1956 absolvovala studium bohemistiky a rusistiky. Poté sedmnáct roků působila jako gymnaziální profesorka nejprve ve Zlíně a později v Olomouci-Hejčíně. V roce 1971 po úspěšném rigorózním řízení získala titul „doktor filozofie“. V roce 1973 na základě konkurzního řízení nastoupila na katedru rusistiky olomoucké filozo- 